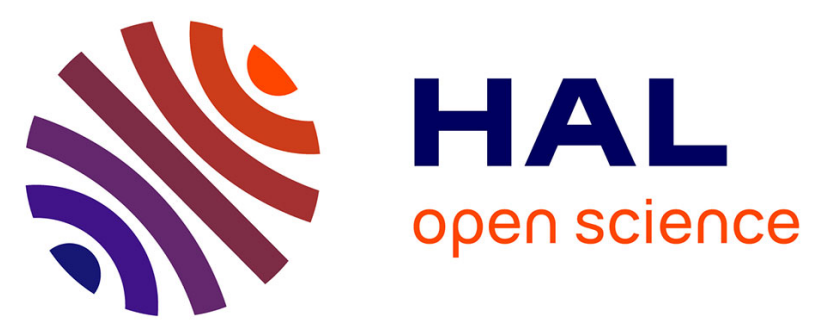

\title{
Using spectrocolourimetry to trace sediment source dynamics in coastal catchments draining the main Fukushima radioactive pollution plume (2011-2017)
}

O. Evrard, Roxanne Durand, Anthony Foucher, Tales Tiecher, Virginie Sellier, Yuichi Onda, Irene Lefevre, Olivier Cerdan, J. Patrick Laceby

\section{To cite this version:}

O. Evrard, Roxanne Durand, Anthony Foucher, Tales Tiecher, Virginie Sellier, et al.. Using spectrocolourimetry to trace sediment source dynamics in coastal catchments draining the main Fukushima radioactive pollution plume (2011-2017). Journal of Soils and Sediments, 2019, 19, pp.3290-3301. $10.1007 / \mathrm{s} 11368-019-02302-\mathrm{w}$. hal-02380977

\section{HAL Id: hal-02380977 https://hal.science/hal-02380977}

Submitted on 26 May 2020

HAL is a multi-disciplinary open access archive for the deposit and dissemination of scientific research documents, whether they are published or not. The documents may come from teaching and research institutions in France or abroad, or from public or private research centers.
L'archive ouverte pluridisciplinaire HAL, est destinée au dépôt et à la diffusion de documents scientifiques de niveau recherche, publiés ou non, émanant des établissements d'enseignement et de recherche français ou étrangers, des laboratoires publics ou privés. 
1

SEDIMENT FINGERPRINTING IN THE CRITICAL ZONE

2

3 Using spectrocolorimetry to trace sediment source dynamics in coastal catchments draining the 4 main Fukushima radioactive pollution plume (2011-2017)

5

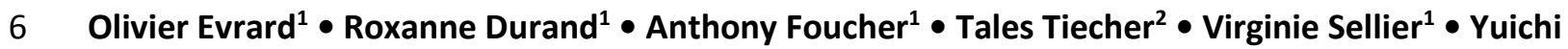

$7 \quad$ Onda $^{3} \bullet$ Irène Lefèvre $^{1} \bullet$ Olivier Cerdan $^{4} \bullet$ J. Patrick Laceby ${ }^{5}$

8

$9{ }^{1}$ Laboratoire des Sciences du Climat et de l'Environnement (LSCE/IPSL), Unité Mixte de Recherche 108212 (CEA/CNRS/UVSQ), Université Paris-Saclay, Gif-sur-Yvette, France (2)
${ }^{2}$ Department of Soil Science, Federal University of Rio Grande do Sul (UFRGS), Porto Alegre, RS, Brazil

${ }^{3}$ Center for Research in Isotopes and Environmental Dynamics (CRIED), University of Tsukuba,

13 Tsukuba, Japan

$14{ }^{4}$ Bureau de Recherches Géologiques et Minières (BRGM), DRP/RIG, Orléans, France

$15{ }^{5}$ Environmental Monitoring and Science Division (EMSD), Alberta Environment and Parks (AEP), 3115

$16-12$ Street NE, Calgary, Alberta, Canada

17

18

$19 \square$ Olivier Evrard

20 olivier.evrard@Isce.ipsl.fr 


\section{Abstract}

Purpose. Spectrocolorimetric measurements provide a relatively inexpensive, quick and nondestructive alternative to the analysis of geochemical and organic matter properties. When analyzed on sediments and their potential sources, these colour parameters may provide important information on the dominant processes (i.e. erosion) occurring in the Critical Zone. Here, they are used to investigate whether eroded sediment is derived from forest (i.e. natural), cultivated (i.e. anthropogenic) or subsoil sources in order to assess their potential to monitor the effect of decontamination in regions impacted by fallout from the Fukushima Dai-ichi Nuclear Power Plant (FDNPP) accident.

Materials and methods. Fifteen spectrocolorimetric properties $\left(L^{*}, a^{*}, b^{*}, C^{*}, h, x, y, z, L, a, b, u^{*}, v^{*}\right.$, $\left.u^{\prime}, v^{\prime}\right)$ were measured in potential source $(n=37)$ and sediment $(n=400)$ samples collected during 13 campaigns from 2011-2017 after major flood events in two catchments (total surface area of $450 \mathrm{~km}^{2}$ ) draining the main Fukushima Dai-ichi Nuclear Power Plant (FDNPP) radioactive pollution plume. Potential sources included topsoil from forest and cultivated sources along with subsoil material originating from landslides, channel banks and the decontamination of cultivated areas. The optimum set of parameters used in the mixed linear model to calculate the sediment source contributions was obtained through the use of a range test, the Kruskal-Wallis $\mathrm{H}$-test, and a linear discriminant analysis.

Results and discussion. Nine selected colour parameters correctly classified $100 \%$ of the source samples (i.e., forest, subsoil and cultivated sources). The results illustrate that cultivated landscapes were the main source of sediment to these river systems (mean 56\%, SD 34\%) followed by subsoil (mean 26\%, SD 16\%) and forest sources (mean 21\%, SD 24\%). However, these contributions varied strongly over time, with a peak of subsoil contributions (mean 57\%, SD 17\%) in Fall 2015, coinciding with the occurrence of a typhoon after the remediation works. These results were consistent with monitoring studies conducted in the same area that showed the major impact of typhoon Etau in September 2015 on sediment and radiocesium fluxes.

Conclusions. These original results demonstrate that spectrocolorimetric measurements may contribute to the routine monitoring of the effectiveness of remediation works in this post-accidental context. Owing to the inexpensive, rapid and non-destructive analyses, spectrocolorimetric-based tracing methods have significant potential to provide information on the dominant erosion processes occurring in the Critical Zone. 


\section{Introduction}

Obtaining quantitative information on the main sources delivering sediment to river networks is required to improve our knowledge of hydro-sedimentary processes occurring in the Critical Zone and also to implement effective soil erosion management programs (Owens et al. 2005). Information on sediment provenance is necessary to reduce the deleterious effects associated with excessive sediment loads to downstream aquatic ecosystems (Minella et al. 2008, Navas et al. 2014, Le Gall et al. 2017). In particular, it is important to understand the origin of the fine-grained fraction of sediment, which is chemically-active and thus facilitates the downstream transfer of contaminants and nutrients (Laceby et al. 2017). Among these contaminants, fallout radionuclides (i.e. radiocesium) are preferentially bound to fine-grained sediment (He \& Walling 1996) and predominantly transferred downstream in particulate form following nuclear accidents (Evrard et al. 2015).

Fluvial fingerprinting techniques provide sediment source information, based on the measurement of conservative biogeochemical and/or physical parameters in both source and sediment material (Haddadchi et al. 2013, Walling 2013, Owens et al. 2016). In general, the choice of tracing properties, or fingerprints, is guided by the sources requiring discrimination. Geochemical measurements are often used to discriminate between different soil types or lithologies (Douglas et al. 2003, Laceby et al. 2015), whereas organic matter composition may trace different land use sources (Thothong et al. 2011, Garzon-Garcia et al. 2017). Many of these conventional tracing properties often require destructive biogeochemical measurements. Furthermore, the preparation of the samples prior to these analyses may have a significant impact on the source apportionment results. For example, the total or partial dissolution of solid samples before geochemical measurements with Inductively Coupled Plasma-Mass Spectrometry (Dabrin et al. 2014) or the destruction of carbonates before carbon and nitrogen isotope analysis with Isotope-Ratio Mass Spectrometry (Harris et al. 2001) may affect sediment fingerprinting parameters.

In contrast, the analyses of physical sediment parameters are generally non-destructive and do not require pre-treatments that may affect source apportionment results. Among these parameters, the 
80

1

2

3

4

6

colour of material, corresponding to the radiation reflected by the material components in the visible

81 region of the electromagnetic spectrum (400-700 nm), has long been used to describe soils (Viscarra 82 Rossel et al. 2006) and material transiting river networks (Strunk 1992). In early sediment fingerprinting research, this tracer was used to provide qualitative sediment source information (Grimshaw \& Lewin 1980). The improvement of spectroscopic techniques then resulted in an increase in the number of studies using this relatively quick and inexpensive technique quantitatively to trace sediment sources (Debret et al. 2011). For example, sediment has been traced with the visible (Pulley \& Rowntree 2016), mid-infrared or near-infrared regions of the spectra (Poulenard et al. 2009), or a combination of these regions (Brosinsky et al. 2014). Furthermore, colour parameters have also been combined with conventional sediment source tracers, such as geochemical elements (Tiecher et al. 2015).

Different approaches have been developed to include the colour-derived parameters quantitatively in sediment source fingerprinting research. Colour coefficients from the visible spectra have been used in mixed linear models to predict sediment source contributions (Martínez-Carreras et al. 2010a). An alternative consisted in using the raw spectra in the visible range to estimate the concentrations of geochemical properties, which were then used in an optimized mixing model to quantify sediment provenance (Martínez-Carreras et al. 2010b). Other studies used visible spectroscopy to estimate the proportions of minerals, such as hematite and goethite (Tiecher et al. 2015) or determine the type of organic matter found in sediment based on the analysis of the first derivative reflectance spectra (Debret et al. 2011). Researchers have also estimated source contributions based on partial leastsquare regression (PLSR) models taking information from the entire spectra into account, after calibrating these models with experimental artificial mixtures containing fixed proportions of sources prepared in the laboratory (Poulenard et al. 2012, Evrard et al. 2013).

The use of colour-derived properties in sediment fingerprinting research is most effective in areas with drastic colour differences between sources, for example, black marls, white limestones and coloured molasses in the French Alps (Legout et al. 2013). In Japan, a major colour contrast occurs in coastal catchments exposed to radioactive fallout following the Fukushima Dai-ichi Nuclear Power Plant 
106 (FDNPP) accident. The main soil types in this region are dark-coloured Cambisols and Andisols, or light-

coloured Fluvisols (Fig. 1). Moreover, decontamination works in this region consisted of removing the radiocesium contaminated topsoil (upper $5 \mathrm{~cm}$ ) and replacing it with a new substrate consisting of a light-coloured crushed granite extracted from local quarries (Yasutaka \& Naito 2016).

In this post-nuclear accident context, identifying sources supplying the material transiting river systems, and the spatial and temporal dynamics of sediment sources, is fundamental to quantifying the effectiveness of remediation strategies and for defining future priorities for the management of radiocesium-contaminated environments. Previous studies based on the destructive analysis of geochemical and organic matter properties identified cultivated sources (e.g. paddy fields) and Fluvisols as the main sources of sediment (Lepage et al. 2014, Laceby et al. 2016b, Huon et al. 2018). However, the replication of these analyses on a large number of samples is time-consuming and may result in insufficient material for future analyses, in particular for sediment samples already analyzed by multiple destructive techniques. As a significant amount of funds are invested in the management of this post-fallout environment, we require multiple lines of evidence to support initial results regarding the dominant source of radiocesium-contaminated particulate matter in this region. 121 Accordingly, the utility of a rapid, low-cost, non-destructive colour tracing technique, combined with 122 non-destructive radiocesium measurements, was investigated in order to provide further 123 understanding of the main spatial and temporal sediment sources dynamics in two catchments draining the main radioactive contamination plume of the FDNPP accident.

\section{Materials and methods}

\subsection{Study site}

This study was conducted in the Niida $\left(275 \mathrm{~km}^{2}\right)$ and Mano $\left(175 \mathrm{~km}^{2}\right)$ catchments (Fig. 2) in the Fukushima Prefecture, Japan. The upper catchment areas are mainly covered with forests, although paddy fields are found in the floodplains along the river channel. These upper catchment areas were heavily contaminated by radiocesium fallout $\left({ }^{134} \mathrm{Cs}+{ }^{137} \mathrm{Cs}\right)$, with initial activities ranging from 20 to 150 
$\mathrm{kBq} \mathrm{kg}^{-1}$. The middle section of these catchments is exclusively forested and characterized by very

steep slope gradients (Chartin et al. 2013). Downstream, the coastal plains are densely cultivated and inhabited with initial fallout contamination from radiocesium not exceeding $20 \mathrm{kBq} \mathrm{kg}^{-1}$ (Lepage et al. 2014). In the headwaters, the main soil types are Cambisols and Andisols, whereas in the coastal plains, 136 Fluvisols are ubiquitous. The mean annual rainfall in the region, located within a $100 \mathrm{~km}$ radius from the FDNPP, is $1420 \mathrm{~mm}$ (Laceby et al. 2016a). The frequent occurrence of typhoons or tropical storms were found to drive sediment generation and radiocesium export from upper catchment areas to the Pacific Ocean (Chartin et al. 2017). In the upper catchment areas, the local population was evacuated after the nuclear accident during Spring in 2011, and these zones were only reopened to inhabitants early on April 1, 2017. However, it is estimated that only $\sim 10 \%$ of the population that lived in these areas before the accident had returned home by December 2018 (litate Village authorities, unpublished data).

\subsection{Source and sediment sampling}

Soil samples $(n=37)$ were collected in areas representative of the main potential sediment sources in the region, including forests ( $n=12$ ), cultivated soils $(n=8)$, subsoil sources ( $n=6)$ (i.e. channel bank, mass movements) and decontaminated material $(n=11)$. Source sampling was restricted to those areas draining to the uppermost river sections, where erosion processes are the most active. Furthermore, soil erosion remains very limited in the flat coastal plain, and those very steep and forested areas located in the middle section of the catchment are very difficult to access. Samples were collected with a plastic trowel, compositing 10 grab subsamples (top 1-2 cm) into one well-mixed and homogenized sample for analysis. Fine sediment samples $(n=400)$ were collected at 20 sites on the Niida River and 19 sites on the Mano River during twelve fieldwork campaigns occurring every 6 months after the main hydro-sedimentary events (e.g. spring snowmelt, and typhoons) that occurred in the region between November 2011 and November 2017. Fine deposited material was scraped (i.e. the top $1 \mathrm{~cm}$ layer) using a plastic spatula and each sample comprised of $\sim 10$ subsamples collected along a $5 \mathrm{~m}$ 
reach. All the soil and sediment samples were oven-dried at $40^{\circ} \mathrm{C}$ for $\sim 48 \mathrm{~h}$, sieved to $2 \mathrm{~mm}$ prior and

pressed into polyethylene boxes $(\sim 15 \mathrm{~mL})$ for analyses.

For this research, we explicitly analyzed tracer parameters in the $<2 \mathrm{~mm}$ particle size fraction. In the Fukushima region, the abundance of ${ }^{137} \mathrm{Cs}$ fallout resulted in radiocesium being bound to multiple fractions, including fine and coarse sands. For example, Fan et al. (2014) reported a stronger correlation for radiocesium and coarse grain sediment relative to the fine grain fraction. As the objective of this research is to test the potential of colorimetric parameters to monitor the dynamics of sediment contaminated with radiocesium in this post-accidental context, this current research will focus on the $<2 \mathrm{~mm}$ fraction. This choice is supported by measurements of the specific surface area on a selection of source soils ( $n=30)$ and sediment ( $n=162)$ (Lepage et al. 2016). Differences in particle size were found not to be statistically significant (Normality Test (Shapiro Wilk): $p<0.05$; Mann-Whitney U-test: $U=2006, p=0.142$.

\subsection{Radionuclide measurements}

Gamma-emitting radionuclide activities were determined with gamma spectrometry using coaxial HyperPure Germanium detectors (Canberra/Ortec) at the Laboratoire des Science et de I'Environnement. ${ }^{137} \mathrm{Cs}$ activities were measured at the $662 \mathrm{keV}$ emission peak. ${ }^{134} \mathrm{Cs}$ activities were calculated as the mean of activities measured at both $604 \mathrm{keV}$ and $795 \mathrm{keV}$ emission peaks. As the initial radionuclide deposits contained similar ${ }^{134} \mathrm{Cs}$ and ${ }^{137} \mathrm{Cs}$ activity concentrations, with an initial ${ }^{134} \mathrm{Cs} /{ }^{137} \mathrm{Cs}$ activity ratio of $\sim 1$, only ${ }^{137} \mathrm{Cs}$ results were presented in the current research (Chartin et al. 177 2013). ${ }^{137}$ Cs activities were decay-corrected to March 14,2011 , the date of the main radionuclide 178 fallout deposition on soils of the region (Kinoshita et al. 2011).

181 Measurements were taken within a 3-mm target radius using a portable diffuse reflectance 182 spectrophotometer (Konica Minolta CM-700d). All samples were measured in the same polyethylene

\subsection{Spectrocolorimetric measurements}


boxes used for gamma spectrometry (volume $15 \mathrm{~mL}$ ) with a minimum sample quantity of $0.2 \mathrm{~g}$. Although the analysis was systematically made at the same location within the boxes, three measurements were conducted on each sample to take potential heterogeneities into account. Spectral reflectance was obtained with a 10-nm resolution between 360 and $740 \mathrm{~nm}$.

All measurements were taken with the D65 standard illuminant, the $10^{\circ}$ angle observer and with the specular component excluded. The raw data was comprised of the spectral reflectance percentage for each of the 39-wavelength classes, from which eight components of various colorimetry models were derived (Viscarra Rossel et al. 2006). XYZ tristimulus values were calculated based on the colourmatching functions defined in 1931 by the International Commission on Illumination (CIE 1931) that were then transformed into the CIE L*a*b* and the CIE L*u*v* Cartesian coordinate systems based on the equations provided in CIE (1978). The spectrophotometer was calibrated before each set of measurements by making a zero and a white calibration. In total, 15 colour metric parameters were quantified for the source and sediment samples (L, $L^{*}, a, a^{*}, b^{*}, C^{*}, h, x, y, z, b, u^{*}, v^{*}, u^{\prime}$, and $\left.v^{\prime}\right)$.

\subsection{Analyses and modelling}

198 First, the selection of discriminant colorimeteric parameters was performed following three steps: (i) a range test, (ii) the Kruskal-Wallis $\mathrm{H}$-test (KW H-test), and (iii) a discriminant function analysis (DFA). For the range test, the variables with sediment concentrations lying outside the range of sources \pm 1 standard deviation were excluded from further analysis, as recommended by Smith and Blake (2014). Then, the KW H-test was performed to test the null hypothesis $(p<0.05)$ that the sources are belonging 203 to the same population.

204 A multivariate discriminant function analysis (DFA) was then performed to determine the minimum 205 number of variables that maximized the discrimination between the sources. DFA is based on the 206 Wilks' lambda $\left(\Lambda^{*}\right)$ value from the analysis of variance, where the criterion used by the statistical model 207 is the minimization of $\Lambda^{*}$. A $\Lambda^{*}$ value of 1 is found when all the group means are the same whilst a low $\Lambda^{*}$ value means that the variability within the groups is small compared to the total variability. The 
DFA was performed in the backward mode, with 0.01 as the maximum or minimum significance of $F$

to include or remove a property.

Second, a modified version of the classical Solver-based mixing model determined the relative contribution of different sources to in-stream sediment through simultaneously minimizing the mixing model difference (MMD):

$$
M M D=\sum_{i=1}^{n}\left(\left(\mathrm{C}_{i}-\left(\sum_{s=1}^{m} \mathrm{P}_{\mathrm{s}} \mathrm{S}_{\mathrm{si}}\right)\right) / \mathrm{C}_{i}\right)^{2}
$$

215 where $n$ is the number of parameters in the model chosen by the three-step selection process; $C_{i}$ is the 216 in-stream sample parameter (i); $m$ is the number of sources; $P_{s}$ is the contribution of source (s); $S_{s i}$ is 217 the mean of parameter (i) in source (s). The proportional contribution from each source $\left(P_{s}\right)$ was 218 modelled by solving Equation 1 with the Solver Function in Microsoft Excel with $P_{s}$ being between 0 219 and 1 and the sum of all $P_{s}$ estimations equalling 1. The GRG Non-Linear solving method was used with 220 automatic scaling in Solver, ignoring integer constraints, with a maximum run time of 5000 and 221 allowing for 2500 iterations. A multi-start population size of 2500 was used along with the same 222 random seed for each of the model runs while requiring bounds on the variables. A constraint precision 223 and convergence of 0.000001 were selected.

\section{Results}

\subsection{Comparing colour parameters between sources and target sediments}

All 15 colorimetric parameters analyzed systematically plotted within the range of values observed in the three main potential sources of riverine material (Fig. 3). The range test demonstrates that the values of our sediment parameters plot within our source range and thus it is possible to use endmember mixing models to quantify the source contributions to target sediment samples. The fact that 
all the sediment samples plot within the source range further infers that there may not be any significant particle size impacts affecting the colorimetric parameters nor missing sources.

\subsection{Colorimetric parameters selection for modelling}

When considering all three potential sources of sediment, all 15 colorimetric parameters were selected as potentially discriminant by the $\mathrm{KW} H$-test (Table 1 ). Among these parameters, 13 were selected by the backward DFA as the best combination to discriminate between the sources $\left(L^{*}, a^{*}, b^{*}, C^{*}, h, x, y\right.$, $v^{\prime}, L, a, b, u^{\prime}, v^{*}$; Table 2). Although the forest and cultivated source samples were well classified using this approach, only 75 to $88 \%$ of the subsoil and decontaminated source samples were attributed to the correct class. Moreover, the uncertainty of classification for these two sources was high (13-26\%; Table 2). This illustrates the difficulty in discriminating between these two subsoil sources (i.e decontaminated or gully/channel bank).

In contrast, when grouping these two classes into a single 'subsoil' category, only nine colorimetric parameters were selected by the DFA $\left(L^{*}, a^{*}, b^{*}, v^{*}, h, a, b, u^{\prime}, L ;\right.$ Table 2$)$. When considering three sources only (i.e. cultivated, forested, and subsoil sources), the DFA is able to classify correctly $100 \%$ of the samples. Furthermore, the uncertainty of the classification of these sources was lower than 0.05\% (Table 2). The improvement in discrimination when merging decontaminated or gully/channel bank into one subsoil source is highlighted in Fig. 4.

\subsection{Source apportionment modelling}

251 The modelling results demonstrate that cultivated soils were the main source of sediment to these 252 river systems between Fall 2011 (mean 57\%) and Spring 2015 (mean 58\%; Fig. 5). Thereafter, their 253 contribution decreased sharply in Fall 2015 (mean 33\%), before increasing again in 2016-2017 (mean 254 range 58-68\%) and exceeding the levels observed between 2011-2015. The contribution of subsoils 255 remained relatively constant during the entire period (mean range 19-25\%), except in Spring 2015 
256 with a peak of 57\%. The supply of sediment originating from forests was higher between 2011-2015

1

2

3

4

(mean range 19-29\%) than in 2016-2017 (mean range 11-18\%).

Despite a clear decrease over the study period (from a mean of $21,920 \mathrm{~Bq} \mathrm{~kg}^{-1}$ in $2011 \mathrm{vs}$. a mean of $5950 \mathrm{~Bq} \mathrm{~kg}{ }^{-1}$ in 2017), ${ }^{137} \mathrm{Cs}$ activities strongly varied in sediment collected at the different sampling locations, between $30-51,590 \mathrm{~Bq} \mathrm{~kg}^{-1}$ in the Niida River, and between $880-27,350 \mathrm{~Bq} \mathrm{~kg}^{-1}$ in the Mano River for the entire study period. A negative correlation $(r=-0.28)$ was observed between the subsoil contributions to sediment sampled in the current research in the upper catchment areas and the ${ }^{137} \mathrm{Cs}$ activities measured in these deposits (Fig. 6). However, this relationship was associated with a low determination coefficient $\left(R^{2}=0.08\right)$ illustrating the complexity of the processes occurring in the study area.

Cultivated soils were modelled to be the dominant source of sediments in the Niida and Mano catchments, followed by subsoil and forest sources. Previous studies demonstrated that soil erosion strongly varied depending on the land use in the Fukushima fallout impacted area, with the highest rates of soil loss and ${ }^{137} \mathrm{Cs}$ wash-off being measured in farmland compared to the much lower rates observed under grassland and forests (Yoshimura et al. 2014).

In the Fukushima region, the top $5 \mathrm{~cm}$ of the soil profile contains upwards of $99 \%$ of the radiocesium contamination (Kato et al. 2012, Lepage et al. 2015). Accordingly, the remediation of radiocesium contamination involves the clearcutting of vegetation and the removal of the 5-cm topsoil. Initially, a light-coloured crushed granite layer corresponding to the 'decontaminated soil' was used to replace the top soil layer prior to this layer being replaced with an organic rich soil. This remediation predominantly occurred on agricultural landscapes (e.g. paddy fields) resulting in the exposure of subsoils and decontaminated soil to the erosive power of rainfall in this region subject to frequent tropical cyclones. 

285 286

The impact of these remediation works on sediment sources was particularly evident in Fall 2015 after

283 the occurrence of typhoon Etau (Chartin et al. 2017), which was the most intense typhoon observed 284 after decontamination had started late in 2013 on the upper section of the Niida River. This may explain the sharp increase of the subsoil contribution of sediment between Spring 2015 (mean 20\%, SD 15\%) and Fall 2015 (mean 57\%, SD 17\%) in both Niida and Mano Rivers as a result of the extensive landslides, the collapse of channel banks and the erosion of subsoil material exposed in decontaminated fields that occurred during this particularly heavy event. However, as cropland remained abandoned in the study area after remediation works have been completed, vegetation regrew quickly and covered these decontaminated soils, which protected them against further erosion. This probably corresponds to subsoil contributions to sediment decreasing again after this period, in both Fall 2016 (mean 22\%, SD 17\%) and Fall 2017 (mean 20\%, SD 14\%).

This phenomenon likely explains the much lower radiocesium concentrations measured in sediment transiting these rivers in 2015 compared to the 2011-2014 period (Evrard et al. 2016). These results were confirmed by Osawa et al. (2018), who demonstrated that radiocesium levels decreased significantly between 2013-2016 in the Mano and the Hiso Rivers. They also highlight the massive sediment and radiocesium fluxes transported during typhoon Etau, in September 2015 (Chartin et al. 2017), which likely explains the very different sediment source contributions calculated in the current research for sediment deposits collected in Fall 2015, after this particularly extreme flooding event. The negative correlation observed between subsoil contributions to sediment and ${ }^{137} \mathrm{Cs}$ activities was expected, as material originating from decontaminated zones and other subsoil material were not exposed to the initial radioactive fallout in 2011, and their contribution therefore diluted the radiocesium contamination supplied to the river by cultivated or forest soils (Evrard et al. 2016). The low determination coefficient associated with this relationship may be explained by the spatial heterogeneity of the initial fallout deposition, with higher levels of ${ }^{137} \mathrm{Cs}$ observed in upper parts of the Niida River catchment (Fig. 2) compared to those observed in upper parts of the Mano River catchment 
307 (Chartin et al. 2013). Furthermore, the local hydro-sedimentary dynamics may also explain the 1

variability in these contamination levels and source contributions at individual sites.

\subsection{Land use-based source contributions to sediment}

The results of the current research may also be compared to those obtained by previous studies quantifying the land use contributions to sediment transiting the Niida and Mano Rivers. Laceby et al. (2016b), using carbon and nitrogen parameters, calculated that cropland provided the most sediment to the Niida River whereas subsoil was the dominant source of material in the Mano River. When comparing the results obtained for those samples analysed by both Laceby et al. (2016) for the $<2 \mathrm{~mm}$ fraction of sediment and the current research $(n=34)$, similar conclusions may be reached for the Niida River. In this catchment, there were similar dominant contributions of cultivated sources to sediment between November 2012 and November 2014 (mean 55\%, SD 31\% in the current research vs. mean 46\%, SD 6\% in Laceby et al. 2016). In contrast, the dominant proportion of subsoil contributions found by Laceby et al. (2016) in the Mano River (mean 62\%, SD 12\%) during this period were not systematically confirmed in the current research (mean 22\%, SD 12\%). The analysis of experimental mixtures prepared in the laboratory and containing known proportions of the individual sources would provide a powerful way of comparing both approaches and investigate whether the colorimetric parameters or the carbon and nitrogen elemental concentrations and stable isotope ratios provide a better approach to trace sediment derived from these different erosion sources.

\subsection{Perspectives for the future monitoring of the impact of remediation}

Although the evolution of radiocesium levels in rivers draining the main radioactive plume in 329 Northeastern Japan has been monitored at several river stations across the Fukushima Prefecture by 330 the Japanese authorities (Fukushima Prefecture 2019, JAEA 2019) and individual research groups (e.g. 331 Osawa et al. 2018), these hydrological and/or hydro-sedimentary records have not been coupled with 332 sediment fingerprinting results. Accordingly, the identification of the sources supplying suspended 
matter transiting these rivers and their spatial and temporal variations could be significantly improved. In this context, the utility of using colour as a discriminant property of sediment sources is that it is easily understandable by local communities and water managers, as colour parameters may act as visual indicators in catchments impacted by the deleterious effects of excessive soil erosion and sedimentation. In the Fukushima Prefecture, changes in sediment colour are associated with a change in the dominant source of material. These changes are easy to identify by the local inhabitants, given the strong colour contrast occurring between the black-coloured sediment originating from forests or paddies and the yellow-coloured material supplied by subsoil (Fig. 7). This tool is therefore appropriate to discuss with the local communities, which are invited to return to this region with the re-opening of the decontaminated areas since April 2017. Local residents could potentially compare the results of this research with their own observations in the field, as it is easy for them to discriminate between, for instance, the dark material originating from forests from the light-coloured sediment supplied by the decontaminated cultivated sources to the rivers. The installation of low-cost colour sensors that may be deployed across a network of monitoring stations in the region could provide more detailed information on the dynamics of contaminated particulate material in this region. Therefore, there is potential to develop a colour based monitoring program to trace the efficacy of decontamination programs in this post nuclear accident context.

\subsection{Perspectives for future tracing research}

352 In the future, other spectrocolorimetric approaches based on the analysis of first derivative values of 353 the reflectance in the visible part of the spectra should be tested (Tiecher et al. 2015). The use of Partial

357 Future research should also combine spectrocolorimetric methods with geochemical indicators, such 358 as X-Ray Fluorescence devices, as geochemistry was shown to provide discrimination between 
Fluvisols found in the local floodplains and Cambisols/Andisols found under forests and cultivated land in these catchments (Lepage et al. 2016). Identifying an additional geochemical property, capable of discriminating between subsoil associated with decontamination works versus subsoil originating from other sources, would provide an unambiguous tracer of remediation and facilitate the development of a more comprehensive approach to understand the efficacy of remediation programs in the Fukushima region.

Furthermore, future research should focus on forests that received the majority of radiocesium fallout after the accident. Importantly, there currently are no plans to decontaminate forested landscapes in the fallout impacted region. In contaminated forests, radiocesium was shown to have almost completely (80-95\%) migrated in 7 years from the litter layer to the mineral layers of the soil, although differences were observed depending on the forest type (Takahashi et al. 2018). Novel tracing approaches, including those based on environmental DNA (Evrard et al. in review) that may discriminate between different plant species, may be beneficial for understanding the impact of forests on in-stream radiocesium contamination.

\section{Conclusions}

Spectrocolorimetric methods were demonstrated to have significant potential to investigate the main sources of sediment (e.g. cultivated, forest or subsoils) in Fukushima coastal catchments draining the main radiocesium contamination plume. However, to fully achieve this goal, these methods should be combined with geochemical measurements, to provide an unambiguous tracer of the decontaminated soil contribution to sediment. This approach will provide results that may help guide the design of programs to monitor the efficacy of decontamination in this post-accidental context as quantifying the subsoil contribution provides straightforward information on the radiocesium content of sediment, as subsurface material was sheltered from the initial radioactive fallout. In the future, these techniques 
could be applied to other types of sediment material types including suspended matter and material accumulated in dam reservoirs in order to check for the consistency of these results for different sample types and compare the current sediment source contributions, including the subsoil proportion, to those reconstructed based on longer term sediment archives. This work is particularly important as the local population has been invited to return to this region and it will likely start to recultivate cropland, which will likely further change the sediment source contributions and hence their potential radiocesium content to these rivers.

Acknowledgements This work has been supported by the French National Research Agency (ANR)

in the framework of the TOFU (ANR-11-JAPN-001) and AMORAD (ANR-11-RSNR-0002) projects. The assistance of Jeremy Patin, Philippe Bonté, Caroline Chartin, Hugo Lepage, Hugo Jaegler, Rosalie Vandromme for fieldwork and/or labwork was greatly appreciated.

\section{References}

Brosinsky A, Foerster S, Segl K, López-Tarazón JA, Piqué G, Bronstert A (2014): Spectral fingerprinting: characterizing suspended sediment sources by the use of VNIR-SWIR spectral information. Journal of Soils and Sediments 14, 1965-1981

Chartin C, Evrard O, Onda Y, Patin J, Lefèvre I, Ottlé C, Ayrault S, Lepage H, Bonté P (2013): Tracking the early dispersion of contaminated sediment along rivers draining the Fukushima radioactive pollution plume. Anthropocene 1, 23-34

Chartin C, Evrard O, Laceby JP, Onda Y, Ottlé C, Lefèvre I, Cerdan O (2017): The impact of typhoons on sediment connectivity: lessons learnt from contaminated coastal catchments of the Fukushima Prefecture (Japan). Earth Surface Processes and Landforms 42, 306-317

CIE C (1978): Publication No. 15, Supplement Number 2 (E-1.3. 1, 1971): Official Recommendations on Uniform Color Spaces, Color-Difference Equations, and Metric Color Terms. Commission Internationale de L'Eclairage

CIE CUPC (1931): Commission internationale de l'eclairage proceedings, 1931.

Dabrin A, Schäfer J, Bertrand O, Masson M, Blanc G (2014): Origin of suspended matter and sediment inferred from the residual metal fraction: Application to the Marennes Oleron Bay, France. Continental Shelf Research 72, 119-130

Debret M, Sebag D, Desmet M, Balsam W, Copard Y, Mourier B, Susperrigui AS, Arnaud F, Bentaleb I, Chapron E, Lallier-Vergès E, Winiarski T (2011): Spectrocolorimetric interpretation of sedimentary dynamics: The new "Q7/4 diagram". Earth-Science Reviews 109, 1-19

Douglas G, Palmer M, Caitcheon G (2003): The provenance of sediments in Moreton Bay, Australia: a synthesis of major, trace element and $\mathrm{Sr}-\mathrm{Nd}-\mathrm{Pb}$ isotopic geochemistry, modelling and landscape analysis, The Interactions between Sediments and Water. Springer, pp. 145-152 
Evrard O, Poulenard J, Némery J, Ayrault S, Gratiot N, Duvert C, Prat C, Lefèvre I, Bonté P, Esteves M (2013): Tracing sediment sources in a tropical highland catchment of central Mexico by using conventional and alternative fingerprinting methods. Hydrological Processes 27, 911-922

Evrard O, Laceby JP, Lepage H, Onda Y, Cerdan O, Ayrault S (2015): Radiocesium transfer from hillslopes to the Pacific Ocean after the Fukushima Nuclear Power Plant accident: A review. Journal of environmental radioactivity $148,92-110$

Evrard O, Laceby JP, Onda Y, Wakiyama Y, Jaegler H, Lefèvre I (2016): Quantifying the dilution of the radiocesium contamination in Fukushima coastal river sediment (2011-2015). Scientific reports 6,34828

Evrard O, Laceby JP, Ficetola GF, Gielly L, Huon S, Lefèvre I, Onda Y, Poulenard J (in review): Environmental DNA provides information on sediment sources: A study in catchments affected by Fukushima radioactive fallout. Science of The Total Environment

Fan Q, Yamaguchi N, Tanaka M, Tsukada H, Takahashi Y (2014): Relationship between the adsorption species of cesium and radiocesium interception potential in soils and minerals: an EXAFS study. Journal of environmental radioactivity $138 \mathrm{C}$, 92-100

Fukushima Prefecture (2019): Rainfall and river monitoring (in Japanese). http://kaseninf.pref.fukushima.jp/gis/. Accessed 3 February 2019.

Garzon-Garcia A, Laceby JP, Olley JM, Bunn SE (2017): Differentiating the sources of fine sediment, organic matter and nitrogen in a subtropical Australian catchment. The Science of the total environment $575,1384-1394$

Grimshaw D, Lewin J (1980): Source identification for suspended sediments. Journal of Hydrology 47, 151-162

Haddadchi A, Ryder DS, Evrard O, Olley J (2013): Sediment fingerprinting in fluvial systems: review of tracers, sediment sources and mixing models. International Journal of Sediment Research 28, 560-578

Harris D, Horwath WR, van Kessel C (2001): Acid fumigation of soils to remove carbonates prior to total organic carbon or CARBON-13 isotopic analysis. Soil Science Society of America Journal $65,1853-1856$

He Q, Walling D (1996): Interpreting particle size effects in the adsorption of ${ }^{137} \mathrm{Cs}$ and unsupported ${ }^{210} \mathrm{~Pb}$ by mineral soils and sediments. Journal of environmental radioactivity $30,117-137$

Huon S, Hayashi S, Laceby JP, Tsuji H, Onda Y, Evrard O (2018): Source dynamics of radiocesiumcontaminated particulate matter deposited in an agricultural water reservoir after the Fukushima nuclear accident. Science of The Total Environment 612, 1079-1090

JAEA (2019): Database for Radioactive Substance Monitoring Data (in English). Japan Atomic Energy Agency. https://emdb.jaea.go.jp/emdb/en/. Accessed 3 February 2019.

Kato $\mathrm{H}$, Onda Y, Teramage M (2012): Depth distribution of ${ }^{137} \mathrm{Cs}$, ${ }^{134} \mathrm{Cs}$, and ${ }^{131} \mathrm{I}$ in soil profile after Fukushima Dai-ichi Nuclear Power Plant Accident. Journal of environmental radioactivity 111, 59-64

Kinoshita N, Sueki K, Sasa K, Kitagawa J, Ikarashi S, Nishimura T, Wong YS, Satou Y, Handa K, Takahashi T, Sato M, Yamagata T (2011): Assessment of individual radionuclide distributions from the Fukushima nuclear accident covering central-east Japan. Proceedings of the National Academy of Sciences of the United States of America 108, 19526-9

Laceby JP, McMahon J, Evrard O, Olley J (2015): A comparison of geological and statistical approaches to element selection for sediment fingerprinting. Journal of Soils and Sediments 15, 2117-2131

Laceby JP, Chartin C, Evrard O, Onda Y, Garcia-Sanchez L, Cerdan O (2016a): Rainfall erosivity in catchments contaminated with fallout from the Fukushima Daiichi nuclear power plant accident. Hydrology and Earth System Sciences 20, 2467-2482

Laceby JP, Huon S, Onda Y, Vaury V, Evrard O (2016b): Do forests represent a long-term source of contaminated particulate matter in the Fukushima Prefecture? Journal of environmental management $183,742-753$ 
Laceby JP, Evrard O, Smith HG, Blake WH, Olley JM, Minella JPG, Owens PN (2017): The challenges and opportunities of addressing particle size effects in sediment source fingerprinting: A review. Earth-Science Reviews 169, 85--103

Le Gall M, Evrard O, Dapoigny A, Tiecher T, Zafar M, Minella JPG, Laceby JP, Ayrault S (2017): Tracing Sediment Sources in a Subtropical Agricultural Catchment of Southern Brazil Cultivated With Conventional and Conservation Farming Practices. Land Degradation \& Development 28, 1426-1436

Legout C, Poulenard J, Nemery J, Navratil O, Grangeon T, Evrard O, Esteves M (2013): Quantifying suspended sediment sources during runoff events in headwater catchments using spectrocolorimetry. Journal of Soils and Sediments 13, 1478-1492

Lepage H, Evrard O, Onda Y, Chartin C, Lefevre I, Sophie A, Bonte P (2014): Tracking the origin and dispersion of contaminated sediments transported by rivers draining the Fukushima radioactive contaminant plume, IAHS-AISH Proceedings and Reports, pp. 237-243

Lepage H, Evrard O, Onda Y, Lefèvre I, Laceby JP, Ayrault S (2015): Depth distribution of cesium-137 in paddy fields across the Fukushima pollution plume in 2013. Journal of environmental radioactivity $147,157-164$

Lepage H, Laceby JP, Bonté P, Joron J-L, Onda Y, Lefèvre I, Ayrault S, Evrard O (2016): Investigating the source of radiocesium contaminated sediment in two Fukushima coastal catchments with sediment tracing techniques. Anthropocene 13, 57-68

Martínez-Carreras N, Krein A, Gallart F, Iffly JF, Pfister L, Hoffmann L, Owens PN (2010a): Assessment of different colour parameters for discriminating potential suspended sediment sources and provenance: A multi-scale study in Luxembourg. Geomorphology 118, 118-129

Martínez-Carreras N, Krein A, Udelhoven T, Gallart F, Iffly JF, Hoffmann L, Pfister L, Walling DE (2010b): A rapid spectral-reflectance-based fingerprinting approach for documenting suspended sediment sources during storm runoff events. Journal of Soils and Sediments 10 , 400-413

Minella JPG, Walling DE, Merten GH (2008): Combining sediment source tracing techniques with traditional monitoring to assess the impact of improved land management on catchment sediment yields. Journal of Hydrology 348, 546-563

Navas A, Lopez-Vicente M, Gaspar L, Palazon L, Quijano L (2014): Establishing a tracer-based sediment budget to preserve wetlands in Mediterranean mountain agroecosystems (NE Spain). The Science of the total environment 496, 132-43

Osawa K, Nonaka Y, Nishimura T, Tanoi K, Matsui H, Mizogichi M, Tatsuno T (2018): Quantification of dissolved and particulate radiocesium fluxes in two rivers draining the main radioactive pollution plume in Fukushima, Japan (2013-2016). Anthropocene 22, 40-50

Owens PN, Batalla RJ, Collins AJ, Gomez B, Hicks DM, Horowitz AJ, Kondolf GM, Marden M, Page MJ, Peacock DH, Petticrew EL, Salomons W, Trustrum NA (2005): Fine-grained sediment in river systems: environmental significance and management issues. River Research and Applications 21, 693-717

Owens PN, Blake WH, Gaspar L, Gateuille D, Koiter AJ, Lobb DA, Petticrew EL, Reiffarth DG, Smith HG, Woodward JC (2016): Fingerprinting and tracing the sources of soils and sediments: Earth and ocean science, geoarchaeological, forensic, and human health applications. EarthScience Reviews 162, 1-23

Poulenard J, Perrette Y, Fanget B, Quetin P, Trevisan D, Dorioz JM (2009): Infrared spectroscopy tracing of sediment sources in a small rural watershed (French Alps). The Science of the total environment 407, 2808-19

Poulenard J, Legout C, Némery J, Bramorski J, Navratil O, Douchin A, Fanget B, Perrette Y, Evrard O, Esteves M (2012): Tracing sediment sources during floods using Diffuse Reflectance Infrared Fourier Transform Spectrometry (DRIFTS): A case study in a highly erosive mountainous catchment (Southern French Alps). Journal of Hydrology 414-415, 452-462

Pulley S, Rowntree K (2016): The use of an ordinary colour scanner to fingerprint sediment sources in the South African Karoo. Journal of environmental management 165, 253-262 
Smith HG, Blake WH (2014): Sediment fingerprinting in agricultural catchments: A critical reexamination of source discrimination and data corrections. Geomorphology 204, 177-191

Strunk N (1992): Case studies of variations in suspended matter transport in small catchments, Sediment/Water Interactions. Springer, pp. 247-255

Takahashi J, Onda Y, Hihara D, Tamura K (2018): Six-year monitoring of the vertical distribution of radiocesium in three forest soils after the Fukushima Dai-ichi Nuclear Power Plant accident. Journal of environmental radioactivity 192, 172-180

Thothong W, Huon S, Janeau J-L, Boonsaner A, de Rouw A, Planchon O, Bardoux G, Parkpian P (2011): Impact of land use change and rainfall on sediment and carbon accumulation in a water reservoir of North Thailand. Agriculture, Ecosystems \& Environment 140, 521-533

Tiecher T, Caner L, Minella JP, dos Santos DR (2015): Combining visible-based-color parameters and geochemical tracers to improve sediment source discrimination and apportionment. The Science of the total environment 527-528, 135-49

Viscarra Rossel RA, Minasny B, Roudier P, McBratney AB (2006): Colour space models for soil science. Geoderma 133, 320-337

Walling DE (2013): The evolution of sediment source fingerprinting investigations in fluvial systems. Journal of Soils and Sediments 13, 1658-1675

Yasutaka T, Naito W (2016): Assessing cost and effectiveness of radiation decontamination in Fukushima Prefecture, Japan. Journal of environmental radioactivity $151 \mathrm{Pt} 2,512-20$

Yoshimura K, Onda Y, Kato H (2014): Evaluation of radiocaesium wash-off by soil erosion from various land uses using USLE plots. Journal of environmental radioactivity 139, 362-369

\section{Figure captions}

Figure 1 - Illustration of the drastic colour differences between potential sediment sources in coastal catchments affected by fallout from the FDNPP-accident including (a) dark-coloured paddy fields on Andisols; (b) light-coloured subsurface material mobilized by landslides; (c) light-coloured crushed granite extracted from local quarries for the decontamination works.

Figure 2 - Location of the investigated catchments in Japan (A) with 134+137Cs concentrations modelled from Chartin et al. (2013) mapped with elevation (B) along with land use and the location of the sediment and source samples modelled in this current study (C).

Figure 3 - Box-plots of several visible-color parameters measured in the potential sources and in suspended sediment samples. The box indicates the location of the first and third quartiles; the line indicates the median value; whiskers indicate the non-outlier range; circles indicate values outside of the range of $\pm 1 S D$.

Figure 4-Two-dimensional scatterplots of the first and second discriminant functions provided by the stepwise discriminant function analysis (DFA) applied using four (a) and three (b) potential sources of sediment, respectively.

Figure 5 - Mean (and standard deviations) of the source contributions to the sediment transiting both the Mano and Niida Rivers during each fieldwork campaign, from Fall 2011 to Fall 2017, according to the conventional linear un-mixing model. 
565 Figure 6 - Correlation between the subsoil contributions to sediment calculated in the current

1566

2 research and the ${ }^{137} \mathrm{Cs}$ activities measured in sediment collected before 2011-2017 in upper sections of the Mano and Niida Rivers. All ${ }^{137}$ Cs activities were decay-corrected to March 14, 2011 (main fallout period on Japanese land).

Figure 7 - Mean soil colour for the different potential land use sources compared to the darkest/mean/lightest colours observed in sediment analysed in the current research. 
Figure 1 - Illustration of the drastic colour differences between potential sediment sources in coastal catchments affected by fallout from the FDNPP-accident including (a) dark-coloured paddy fields on Andisols; (b) light-coloured subsurface material mobilized by landslides; (c) light-coloured crushed granite extracted from local quarries for the decontamination works.

Figure 2 - Location of the investigated catchments in Japan (A) with 134+137Cs concentrations modelled from Chartin et al. (2013) mapped with elevation (B) along with land use and the location of the sediment and source samples modelled in this current study (C).

Figure 3 - Box-plots of several visible-color parameters measured in the potential sources and in suspended sediment samples. The box indicates the location of the first and third quartiles; the line indicates the median value; whiskers indicate the non-outlier range; circles indicate values outside of the range of $\pm 1 S D$.

Figure 4-Two-dimensional scatterplots of the first and second discriminant functions provided by the stepwise discriminant function analysis (DFA) applied using four (a) and three (b) potential sources of sediment, respectively.

Figure 5 - Mean (and standard deviations) of the source contributions to the sediment transiting both the Mano and Niida Rivers during each fieldwork campaign, from Fall 2011 to Fall 2017, according to the conventional linear un-mixing model.

Figure 6 - Correlation between the subsoil contributions to sediment calculated in the current research and the ${ }^{137} \mathrm{Cs}$ activities measured in sediment collected before 2011-2017 in upper sections of the Mano and Niida Rivers. All ${ }^{137}$ Cs activities were decay-corrected to March 14, 2011 (main fallout period on Japanese land).

Figure 7 - Mean soil colour for the different potential land use sources compared to the 584 darkest/mean/lightest colours observed in sediment analysed in the current research. 


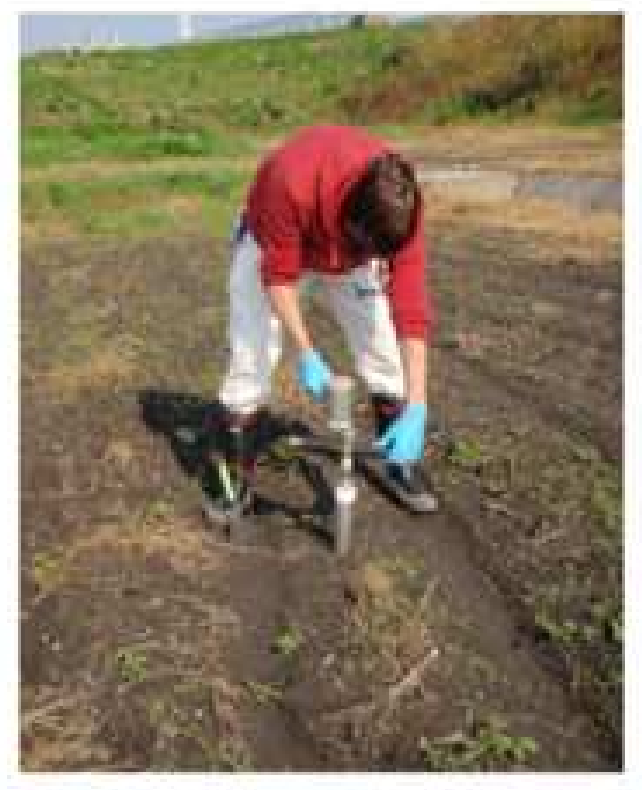

(a)

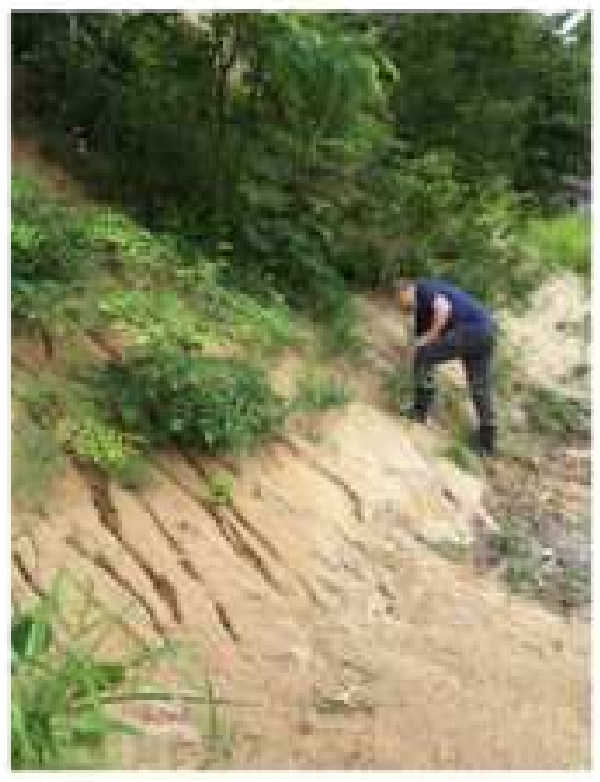

(b)

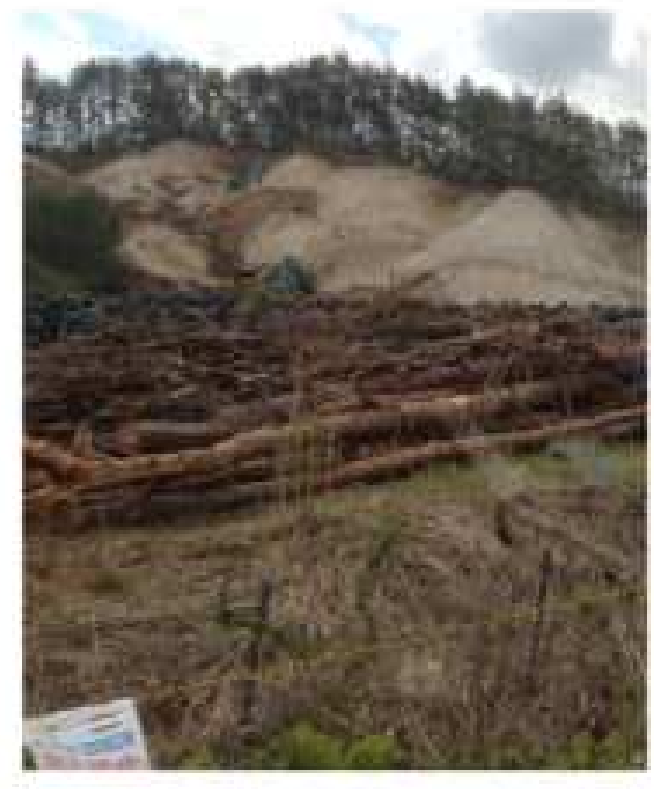

(c) 

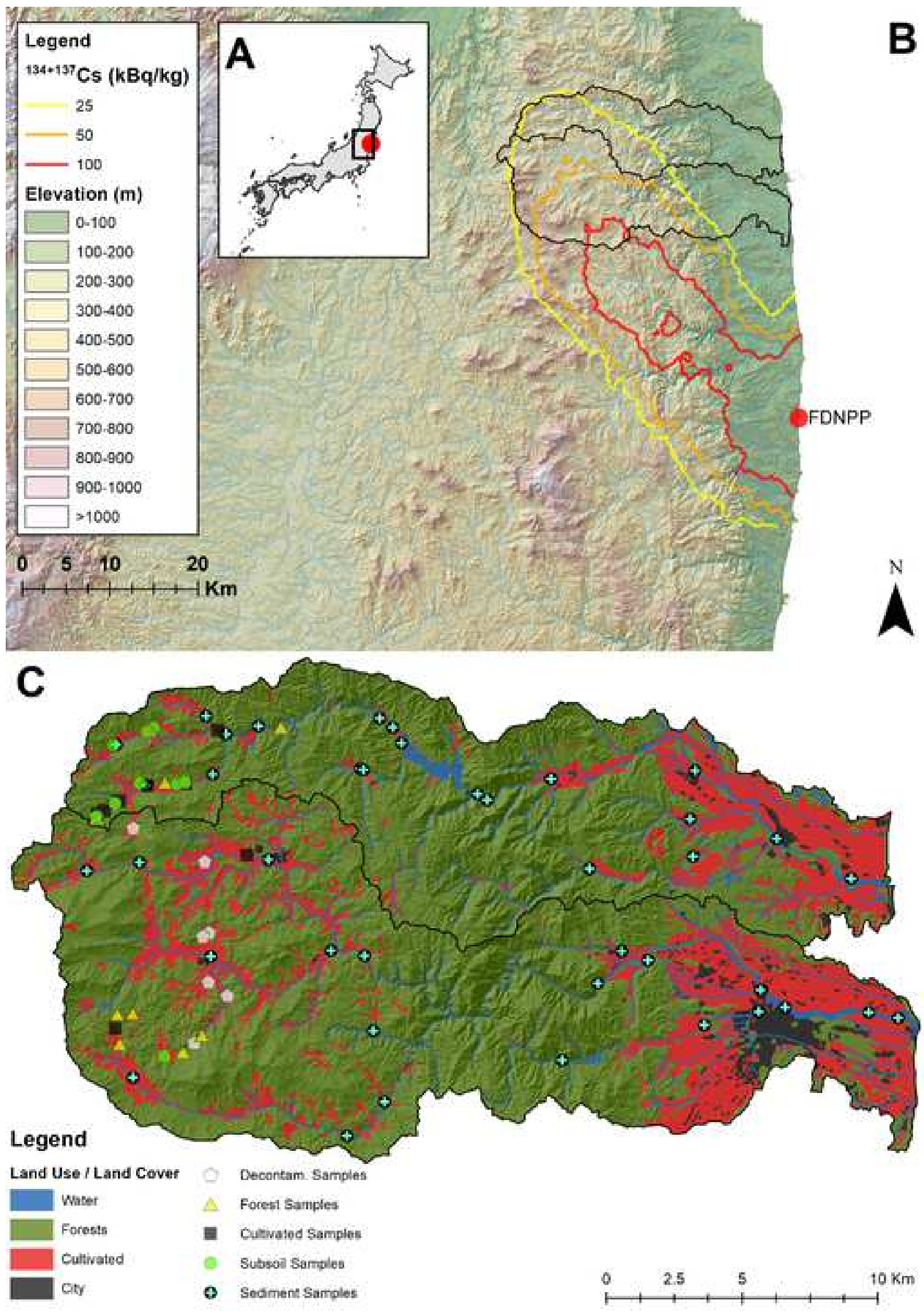

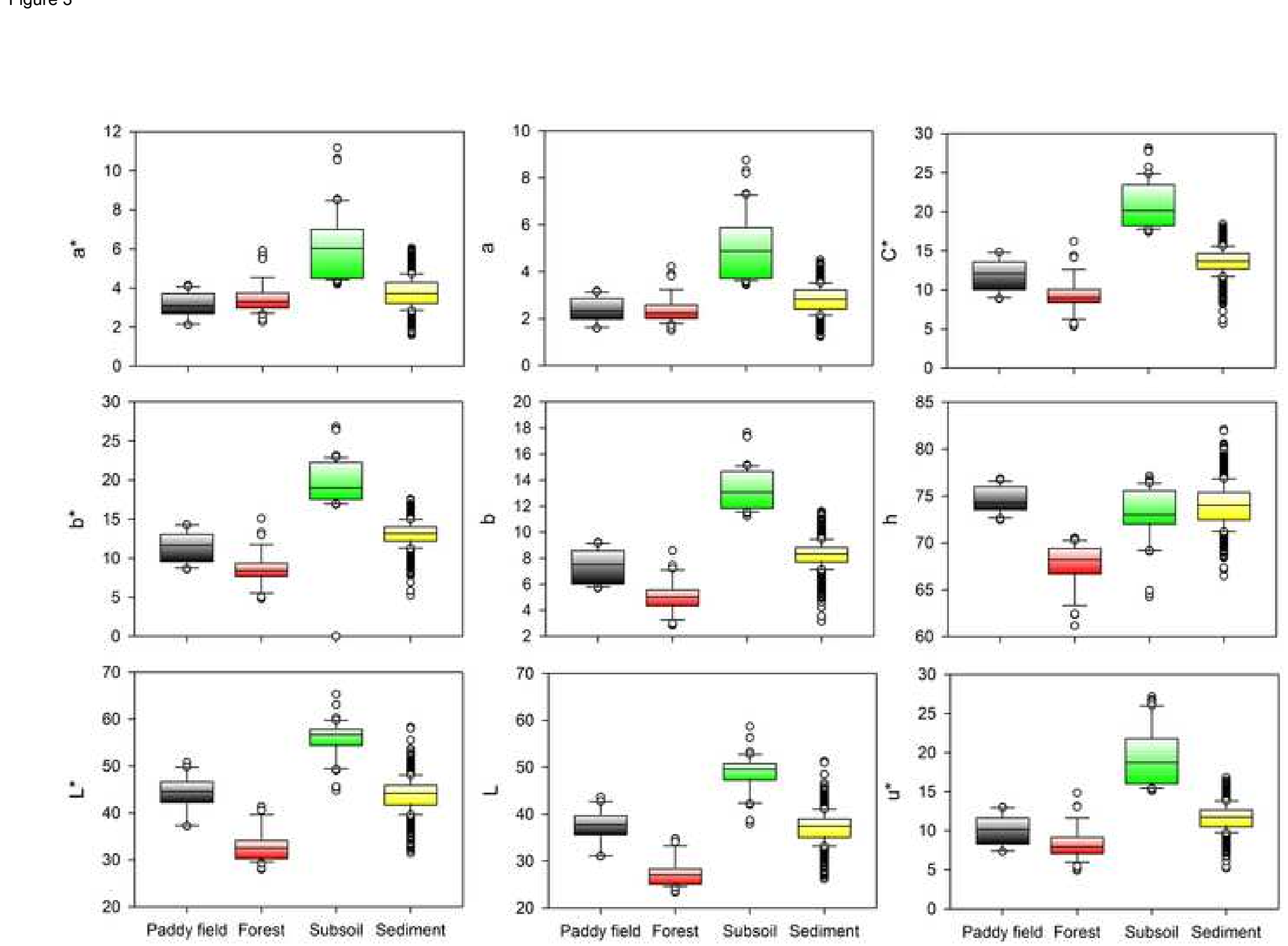

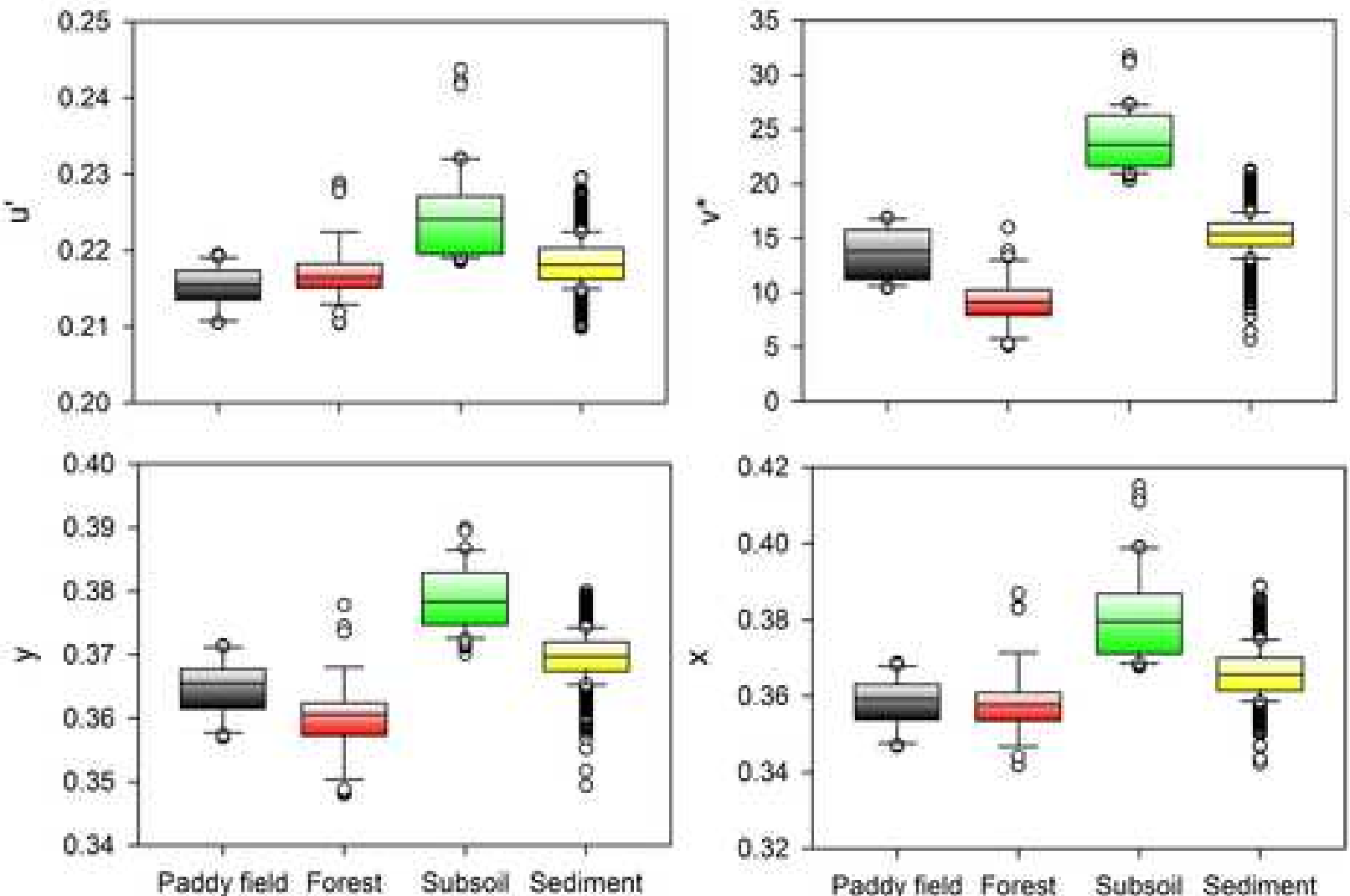

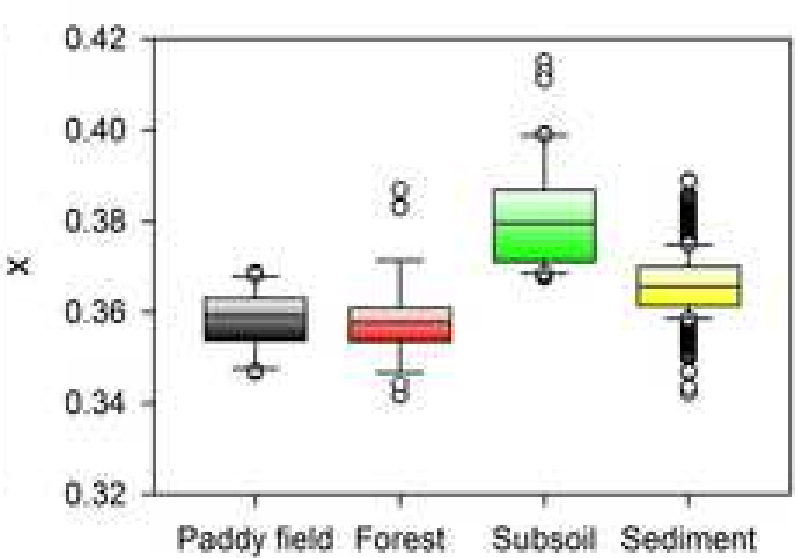

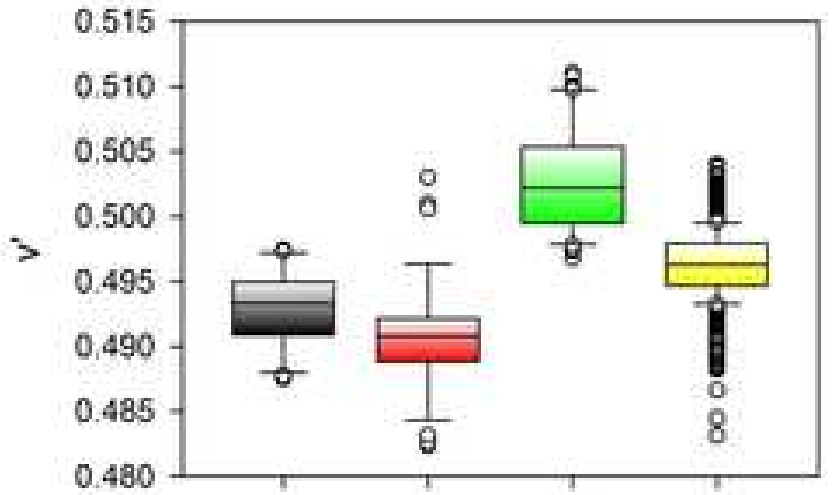

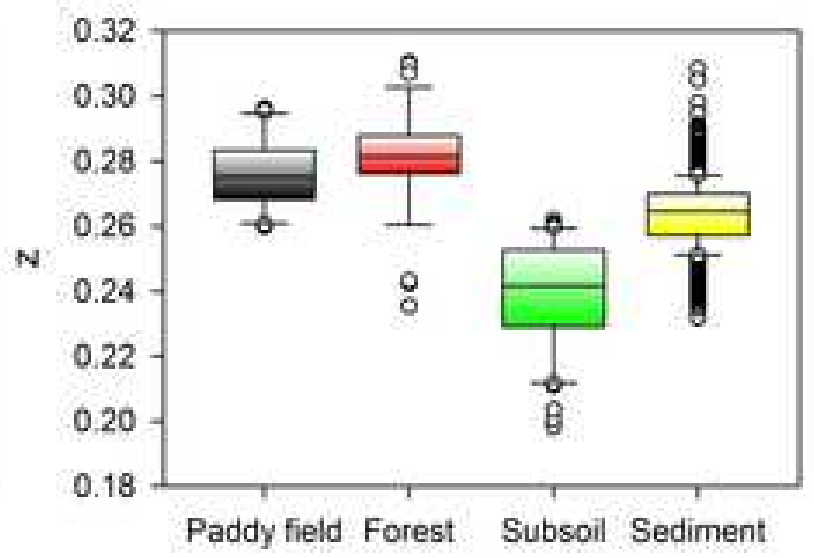


(a) 8

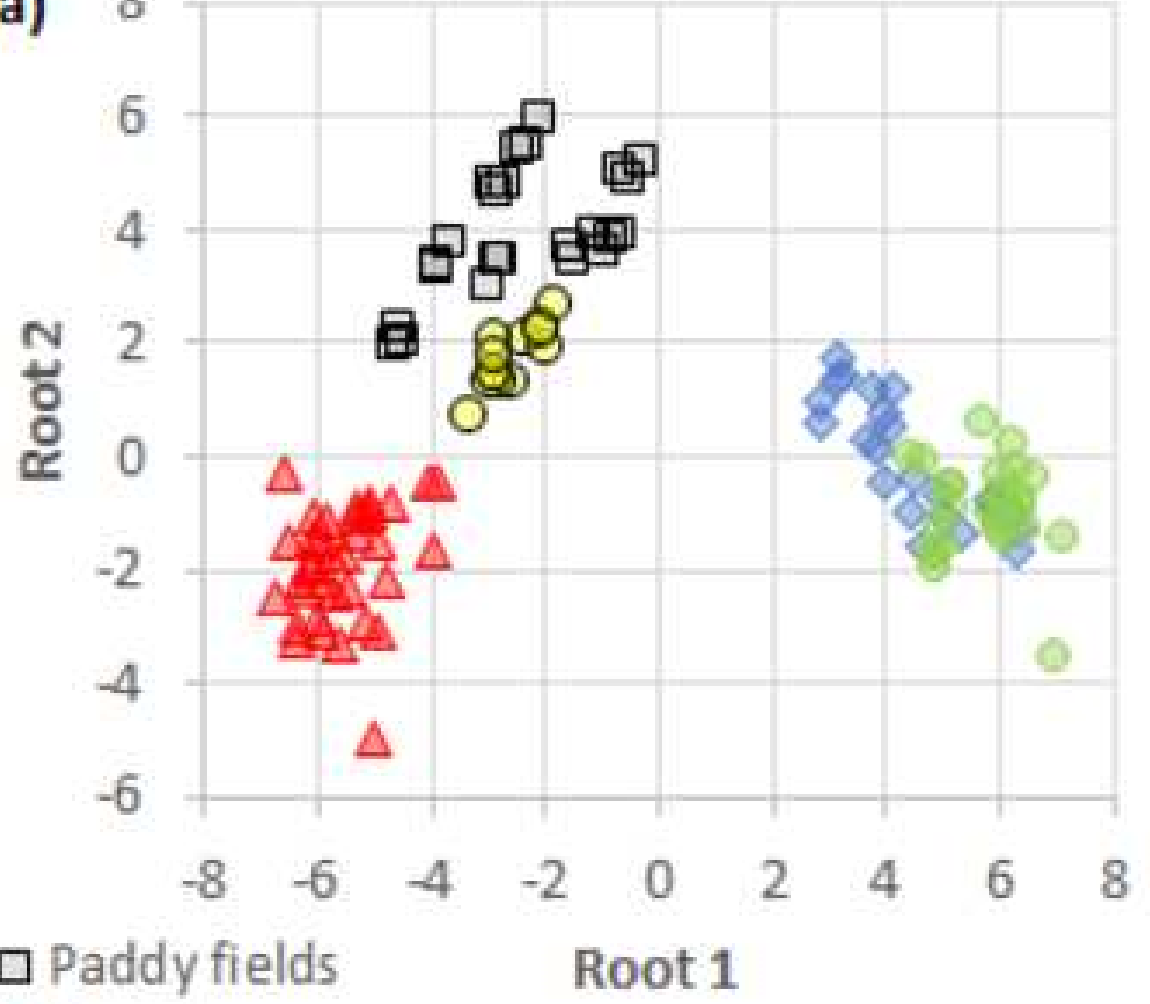

$\triangle$ Forest

$\diamond$ Decontamined subsoil

- Subsoil

o Sediment (b)

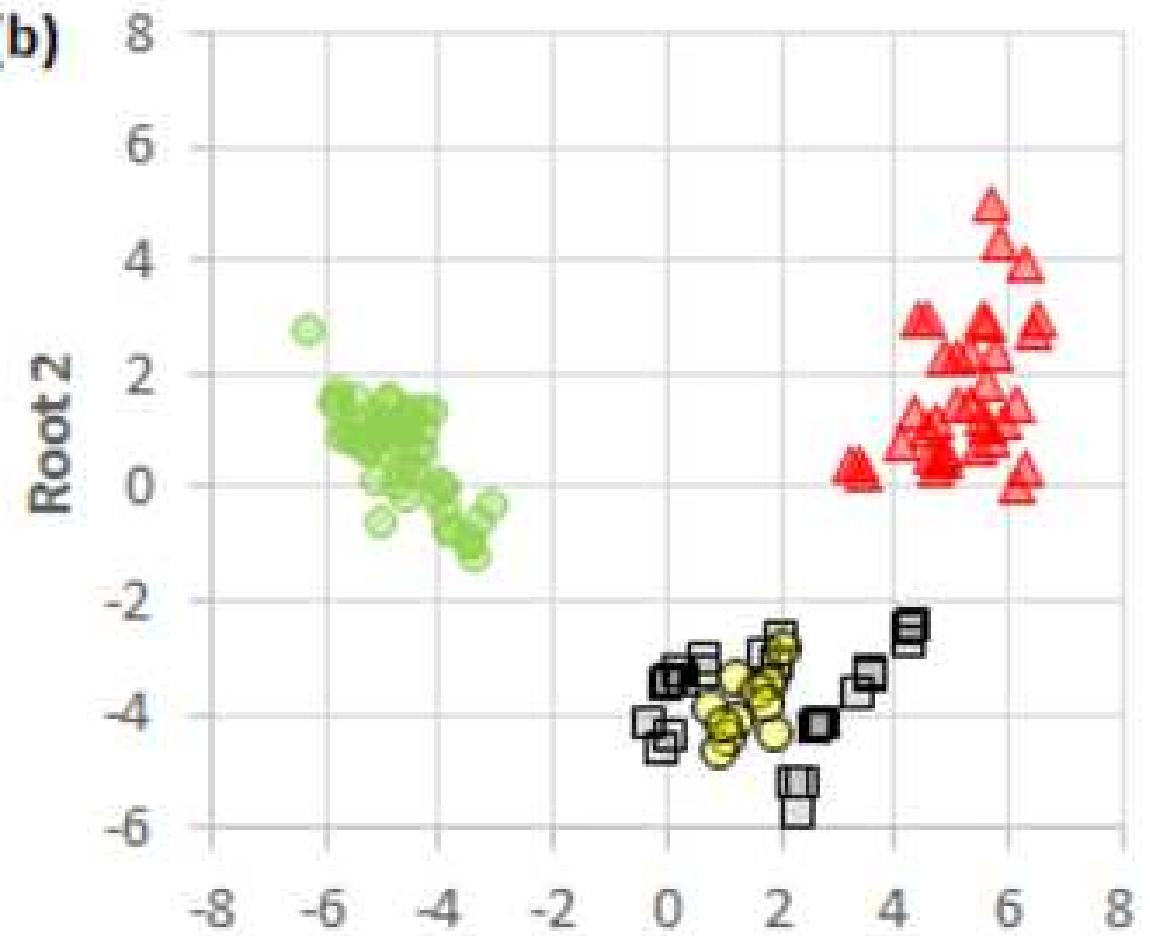

$\square$ Paddy field

Root 1
$\triangle$ Forest
- Subsoil
o Sediment samples 


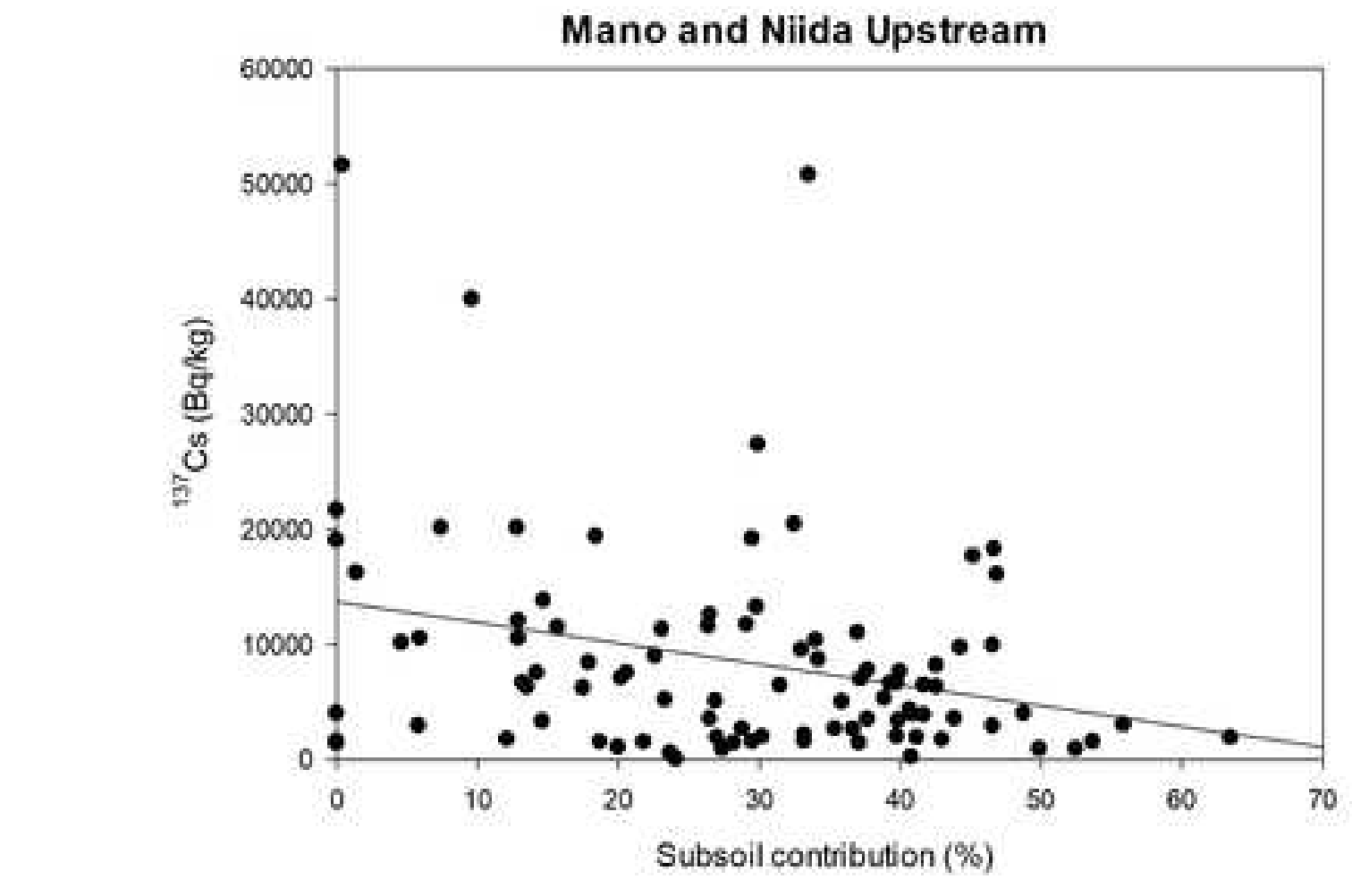

Figure 6 
Table 1.

Kruskal-Wallis $\mathrm{H}$ test results ( $\mathrm{p}$-values) examining the occurrence of significant differences between sources based on colorimetric parameters.

\begin{tabular}{lcccc}
\hline \multirow{2}{*}{$\begin{array}{l}\text { Colour } \\
\text { parameter }\end{array}$} & \multicolumn{2}{c}{ Four source approach } & \multicolumn{2}{c}{ Three source approach } \\
\cline { 2 - 5 } & \multicolumn{2}{c}{ Kruskal-Wallis test } & \multicolumn{2}{c}{ Kruskal-Wallis test } \\
\cline { 2 - 5 } & H-value & p-value & H-value & p-value \\
\hline L $^{*}$ & 90.6 & $<0.001$ & 90.5 & $<0.001$ \\
a $^{*}$ & 79.4 & $<0.001$ & 75.6 & $<0.001$ \\
$\mathrm{~b}^{*}$ & 90.4 & $<0.001$ & 87.7 & $<0.001$ \\
$\mathrm{C}^{*}$ & 90.4 & $<0.001$ & 87.7 & $<0.001$ \\
$\mathrm{~h}$ & 70.6 & $<0.001$ & 63.5 & $<0.001$ \\
$\mathrm{X}$ & 73.8 & $<0.001$ & 71.4 & $<0.001$ \\
$\mathrm{y}$ & 82.8 & $<0.001$ & 80.7 & $<0.001$ \\
$\mathrm{z}$ & 76.6 & $<0.001$ & 74.2 & $<0.001$ \\
$\mathrm{~L}$ & 90.6 & $<0.001$ & 90.5 & $<0.001$ \\
$\mathrm{a}$ & 81.0 & $<0.001$ & 77.0 & $<0.001$ \\
b & 92.7 & $<0.001$ & 90.7 & $<0.001$ \\
$\mathrm{u}^{*}$ & 88.6 & $<0.001$ & 85.3 & $<0.001$ \\
$\mathrm{~V}^{*}$ & 92.6 & $<0.001$ & 90.6 & $<0.001$ \\
$\mathrm{u}^{\prime}$ & 68.7 & $<0.001$ & 65.4 & $<0.001$ \\
$\mathrm{v}^{\prime}$ & 78.7 & $<0.001$ & 76.3 & $<0.001$ \\
\hline
\end{tabular}


Table 2. Results of the discriminant function analysis with four potential sources in the Mano and Niida catchments.

\begin{tabular}{|c|c|c|c|}
\hline DFA parameters & Four source approach & \multicolumn{2}{|c|}{ Three source approach } \\
\hline Selected tracers & $L^{*}, a^{*}, b^{*}, C^{*}, h, x, y, v^{\prime}, L, a, b, u^{\prime}, v^{*}$ & \multicolumn{2}{|c|}{$L^{*}, a^{*}, b^{*}, v^{*}, h, a, b, u^{\prime}, L$} \\
\hline \multicolumn{4}{|c|}{ Source type samples correctly classified (\%) } \\
\hline Forest & 100 & Forest & 100 \\
\hline Subsoil & 88 & Subsoil & 100 \\
\hline Decontaminated subsoil & 75 & Paddy fields & 100 \\
\hline Paddy fields & 100 & - & - \\
\hline Total & 92 & Total & 100 \\
\hline \multicolumn{4}{|c|}{ Uncertainty associated with the discrimination of the source (\%) } \\
\hline Forest & $7.41 \mathrm{E}-04$ & Forest & $9.82 \mathrm{E}-03$ \\
\hline Subsoil & 13.61 & Subsoil & $1.72 \mathrm{E}-06$ \\
\hline Decontaminated subsoil & 23.23 & Paddy fields & $5.30 \mathrm{E}-02$ \\
\hline Paddy fields & 0.18 & - & - \\
\hline
\end{tabular}




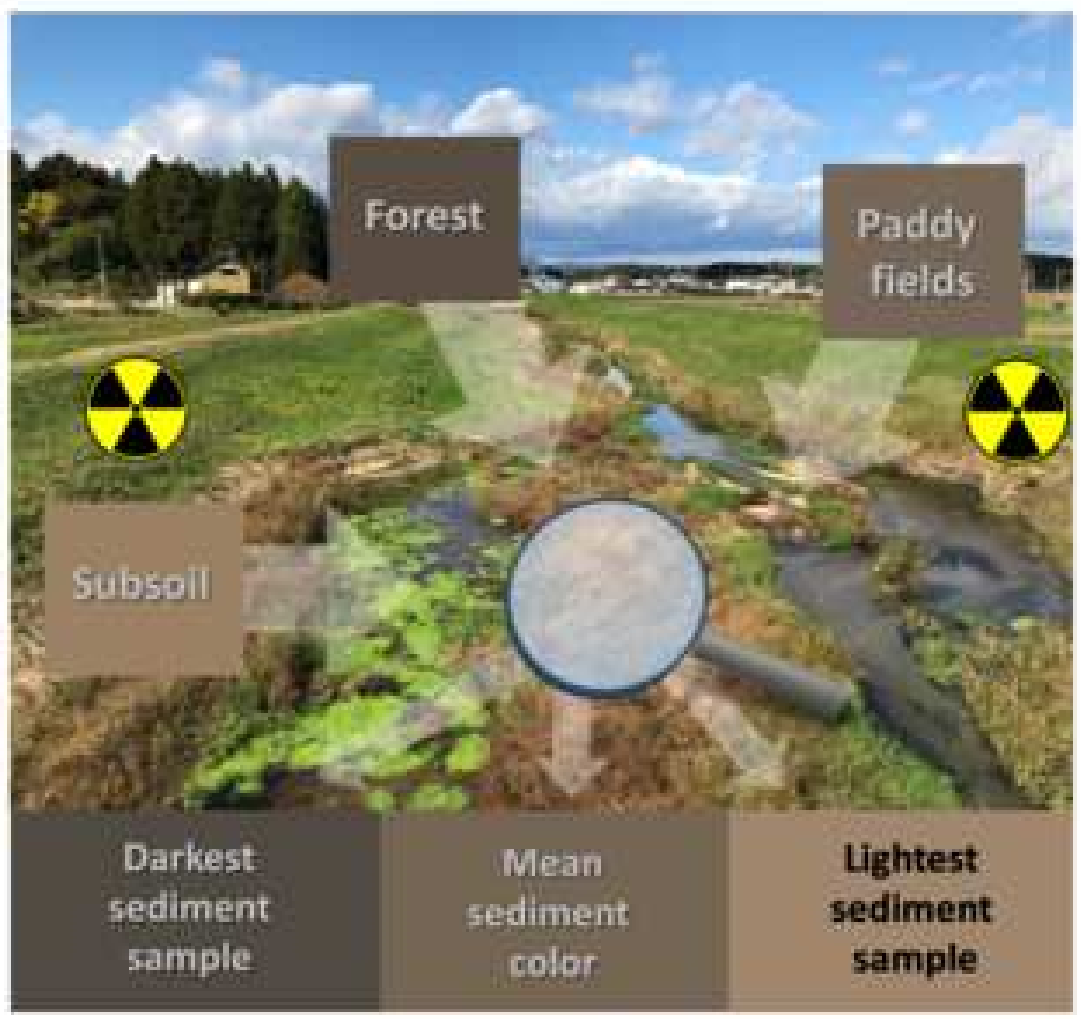

